\title{
Efficacy of Certain Chemical Insecticides against Rice Gundhi Bug (Leptocorisa acuta Thunberg) Under Field Condition
}

\author{
Brajesh Bais*, Ashwani Kumar, Hadi Husain Khan, Ramkinkar Sahu and \\ Pramod Kumar Kaiwart
}

Department of Entomology, Sam Higginbottom University of Agriculture, Technology and Sciences, Allahabad, U.P., India

*Corresponding author

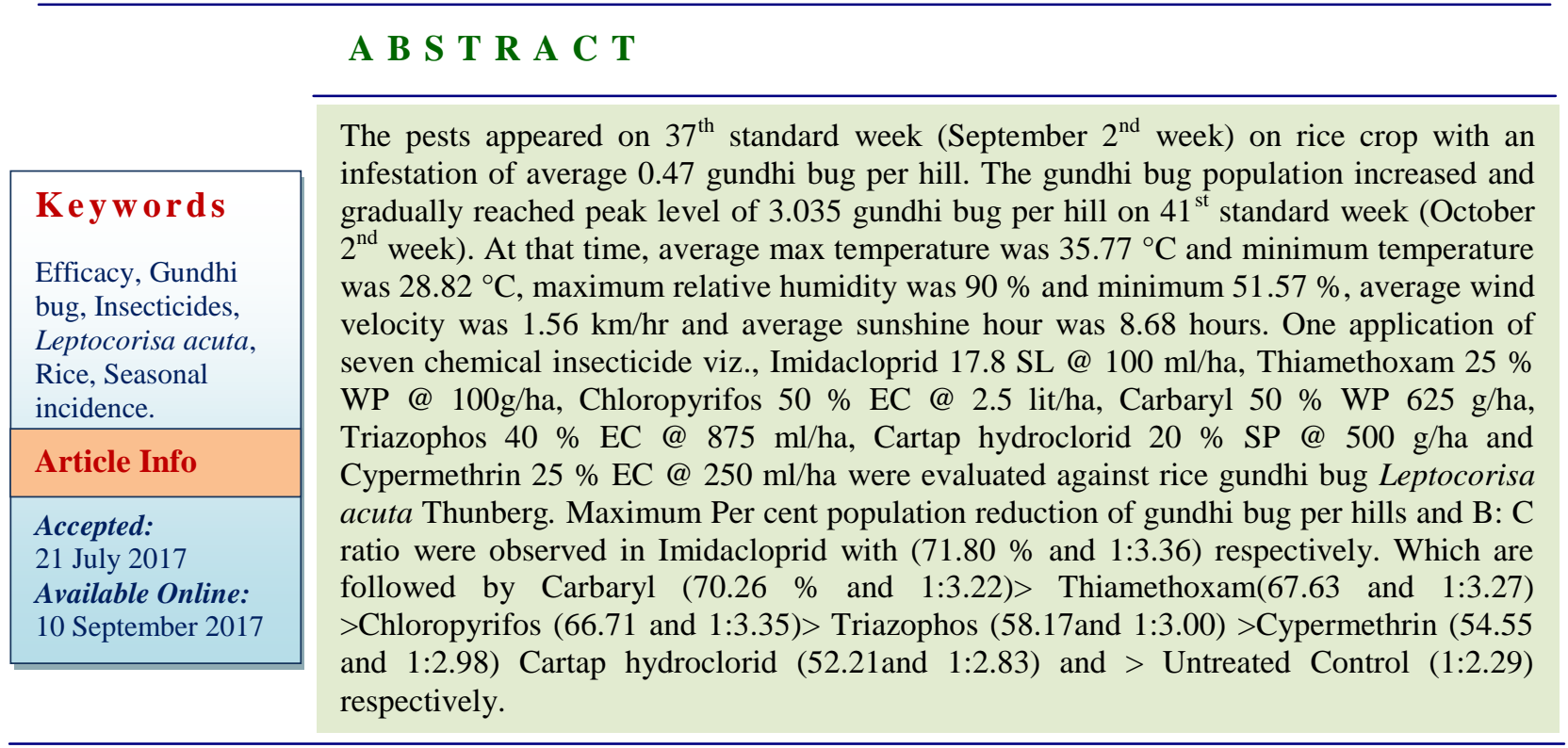

\section{Introduction}

Rice (Oryza sativa L.) is the world's most important food and a primary food source for more than a third of the world's population. India produces 99.15 million tons of rice. Rice, the staple food of more than half of human population is grown in 153.9 million hectares in the world with a production of 618 million tones and a productivity of 4.02 tones/ha. China ranks first in rice production in the world. In India, the area under rice cultivation is 41.90 million hectares with production of 132.02 million tons.
Gundhi Bug (Leptocorisa varicornis Fabricious) is a serious pest of rice and sometimes reduce yield by as much as $30 \%$.

The adults are slender and brown-green. They measure 19-16 mm long.

The younger instars are pale in color. The nymphs have long antennae. The older instars measure 1.8-6.2 $\mathrm{mm}$ long. They are yellowish green. The eggs are oval, shiny, and reddish brown. They are laid in batches of 10-20 in 
one to three rows along the midrib on the upper surface of the leaf.

There are mainly two species, viz., Leptocorisa acuta Thunberg and L. oratorius Fabricious. Rice gundhi bug causes an average loss of $10-30 \%$ yield because of its infestation during milky stage which leads to partial filling of grains/chaffy grains.

The nymphs as well as adults emit a characteristic offensive odour in infested fields, which can be very easily recognized as a signal of presence of gundhi bug in rice fields (Prasad and Prasad, 2006). IPM is an eco-friendly approach for managing pest problems utilizing all possible available methods and techniques of pest control such as cultural, mechanical, biological and chemical methods in a compatible and scientific manner to suppress the pest population below economic injury level.

\section{Materials and Methods}

A field trial was conducted during kharif season of 2016 with IR-6444 variety in research field of department of Entomology, Sam Higginbottom Institute of Agriculture, Technology \& Sciences, Allahabad.

The experiment was laid out in randomized block design, with four replications and eight treatments including untreated check with a plot size of $5 \mathrm{~m} \times 5 \mathrm{~m}$ each. Twenty one days old seedlings were planted with a spacing of $20 \mathrm{x} 10 \mathrm{~cm}$. The treatments comprised of foliar sprays of chemical insecticides, viz., Cypermethrin $25 \%$ EC @ $250 \mathrm{ml} / \mathrm{ha}$, Cartap $20 \%$ SP @ 500 g/ha, Chloropyrifos $50 \%$ EC @ 2.5 ml/ha, Carbaryl 50\%WP @625 g/ha with Triazophos 40 \% EC @ 500 g/ha, Thiamethoxan 25\% WP @ 100 g/ha and Imidacloprid 17.8 SL @ $100 \mathrm{ml} / \mathrm{ha}$ (Yaduman et al., (2015) Tiwari et al., (2014) Rath et al., (2015) Dey et al., (2013).

\section{Results and Discussion}

The pooled data presented in Table land Table 2 indicates that all insecticides were significantly superior over control in reducing the population of gundhi bug recorded at $1^{\text {st }}$, $5 \mathrm{t}^{\mathrm{h}}, 10^{\text {th }}$ and $15^{\text {th }}$ days after insecticidal applications.

Imidacloprid was found significantly superior $(1.32,0.67, .35, .30)$ followed by Chloropyrifos $(1.42, .90, .50, .47)$, Carbaryl $(1.35, .87, .42, .57)$, Thiamethoxam $(1.55, \quad .80, \quad .55, \quad .52)$, Triazophos $(1.62, .82, .62, .82)$ Cartap $(1.65, .75, .72,1.27)$ and Cypermethrin (1.40, $0.97,0.77,1.20)$ as compared to control $(2.32$, $2.60,2.95,3.32)$ at $1^{\text {st }}, 5 \mathrm{t}^{\mathrm{h}}, 10^{\text {th }}$ and $15^{\text {th }}$ days, respectively.

The data for the efficacy of different treatments were evaluated on the basis of per cent population reduction. All the treatments were significant. Per cent population reduction of gundhi bug recorded at $1^{\mathrm{st}}, 5 \mathrm{t}^{\mathrm{h}}$, $10^{\text {th }}$ and $15^{\text {th }}$ days after insecticidal applications of Imidacloprid was found significantly superior $(37.27,72.07,87.69$, 90.10) followed by Carbaryl (44.89, 66.97, $85.94,83.24)$ as compared to other treatments, Thiamethoxam (37.27, 71.05, 82.45, 79.76), Chloropyrifos (35.79, 63.60, $82.17,85.28)$, Triazophos (20.52, 64.02, 76.01, 72.15), Cypermethrin (31.32, 57.44, 70.21, 59.24) and Cartap (16.29,65.97, 71.20, 55.39) respectively. Siminar findings have been reported by Yaduman et al., (2015) Choudhary et al., (2014)

Treatments were found significant among each other in yield comparison. Maximum yield $(\mathrm{q} / \mathrm{ha})$ was recorded in Imidacloprid (45.500) followed by Carbaryl (44.000), Thiamethoxam (43.700), Chloropyrifos (42.000), Triazophas (40.600), Cypermethrin (38.200), and Cartap (37.000) as compared to control (27.500). 
Table.1 Efficacy of certain chemical insecticides against Gundhi bug, Leptocorisa acuta Thunberg during kharif season of 2015: (Population / hills)

\begin{tabular}{|c|c|c|c|c|c|c|c|}
\hline & \multicolumn{6}{|c|}{ Gundhi bug population / hills } \\
\hline $\begin{array}{l}\text { Tr. } \\
\text { No }\end{array}$ & Treatment & $\begin{array}{c}\text { Before } \\
\text { spray }\end{array}$ & $1^{\text {st }}$ DAS & $5^{\text {th }}$ DAS & $10^{\text {th }}$ DAS & $15^{\text {th }}$ DAS & Mean \\
\hline T0 & Control & 2.42 & 2.32 & 2.60 & 2.95 & 3.32 & 2.72 \\
\hline $\mathrm{T} 1$ & Imidacloprid & 2.20 & 1.32 & 0.67 & 0.35 & 0.30 & 0.96 \\
\hline $\mathrm{T} 2$ & Thiamethoxam & 2.57 & 1.55 & 0.80 & 0.55 & 0.52 & 1.19 \\
\hline T3 & Chloropyrifos & 2.30 & 1.42 & 0.90 & 0.50 & 0.47 & 1.11 \\
\hline $\mathrm{T} 4$ & Carbaryl & 2.45 & 1.35 & 0.87 & 0.42 & 0.57 & 1.13 \\
\hline $\mathrm{T} 5$ & Triazophos & 2.12 & 1.62 & 0.82 & 0.62 & 0.82 & 1.20 \\
\hline T6 & Cartap & 2.12 & 1.40 & 0.97 & 0.77 & 1.20 & 1.29 \\
\hline $\mathrm{T} 7$ & Cypermethrin & 2.05 & 1.65 & 0.72 & 0.72 & 1.27 & 1.28 \\
\hline & F.test & NS & $\mathbf{S}$ & $\mathbf{S}$ & $\mathbf{S}$ & $\mathbf{S}$ & $\mathbf{s}$ \\
\hline & $\mathrm{CD}(5 \%)=$ & 0.28 & 0.26 & 0.27 & 0.31 & 0.36 & 0.47 \\
\hline & $\mathrm{S}, \mathrm{ED}\left(+\_\right)$ & 0.13 & 0.12 & 0.13 & 0.15 & 0.18 & 0.22 \\
\hline & $\mathrm{C} \mathrm{V} \%$ & 8.33 & 11.12 & 17.77 & 24.17 & 23.30 & 27.96 \\
\hline
\end{tabular}

Table.2 Efficacy of certain chemical insecticides against gundhi bug Leptocorisa acuta Thunberg during kharif seasion of 2015 : (Per cent population reduction)

\begin{tabular}{|c|c|c|c|c|c|c|c|}
\hline \multicolumn{2}{|c|}{} & \multicolumn{5}{|c|}{ Per cent population reduction of rice gundhi bug /hills } \\
\hline $\begin{array}{r}\text { Tr. } \\
\text { No }\end{array}$ & Treatment & Before Spray & $\mathbf{1}^{\text {st }}$ DAS & $\mathbf{5}^{\text {th }}$ DAS & $\mathbf{1 0}^{\text {th }}$ DAS & $\begin{array}{c}\mathbf{1 5}^{\text {th }} \\
\text { DAS }\end{array}$ & Mean \\
\hline T0 & Control & 2.42 & - & - & - & - & - \\
\hline T1 & Imidacloprid & 2.20 & 37.27 & 72.07 & 87.69 & 90.18 & 71.80 \\
\hline T2 & Thiamethoxam & 2.57 & 37.27 & 71.05 & 82.45 & 79.76 & 67.63 \\
\hline T3 & Chloropyrifos & 2.30 & 35.79 & 63.60 & 82.17 & 85.28 & 66.71 \\
\hline T4 & Carbaryl & 2.45 & 44.89 & 66.97 & 85.94 & 83.24 & 70.26 \\
\hline T5 & Triazophos & 2.12 & 20.52 & 64.02 & 76.01 & 72.15 & 58.17 \\
\hline T6 & Cartap & 2.12 & 31.32 & 57.44 & 70.21 & 59.24 & 54.55 \\
\hline T7 & Cypermethrin & 2.05 & 16.29 & 65.97 & 71.20 & 55.39 & 52.21 \\
\hline
\end{tabular}


Fig.1 Graphical representation of efficacy of certain chemical insecticides against gundhi bug,

Leptocorisa acuta Thunberg on rice

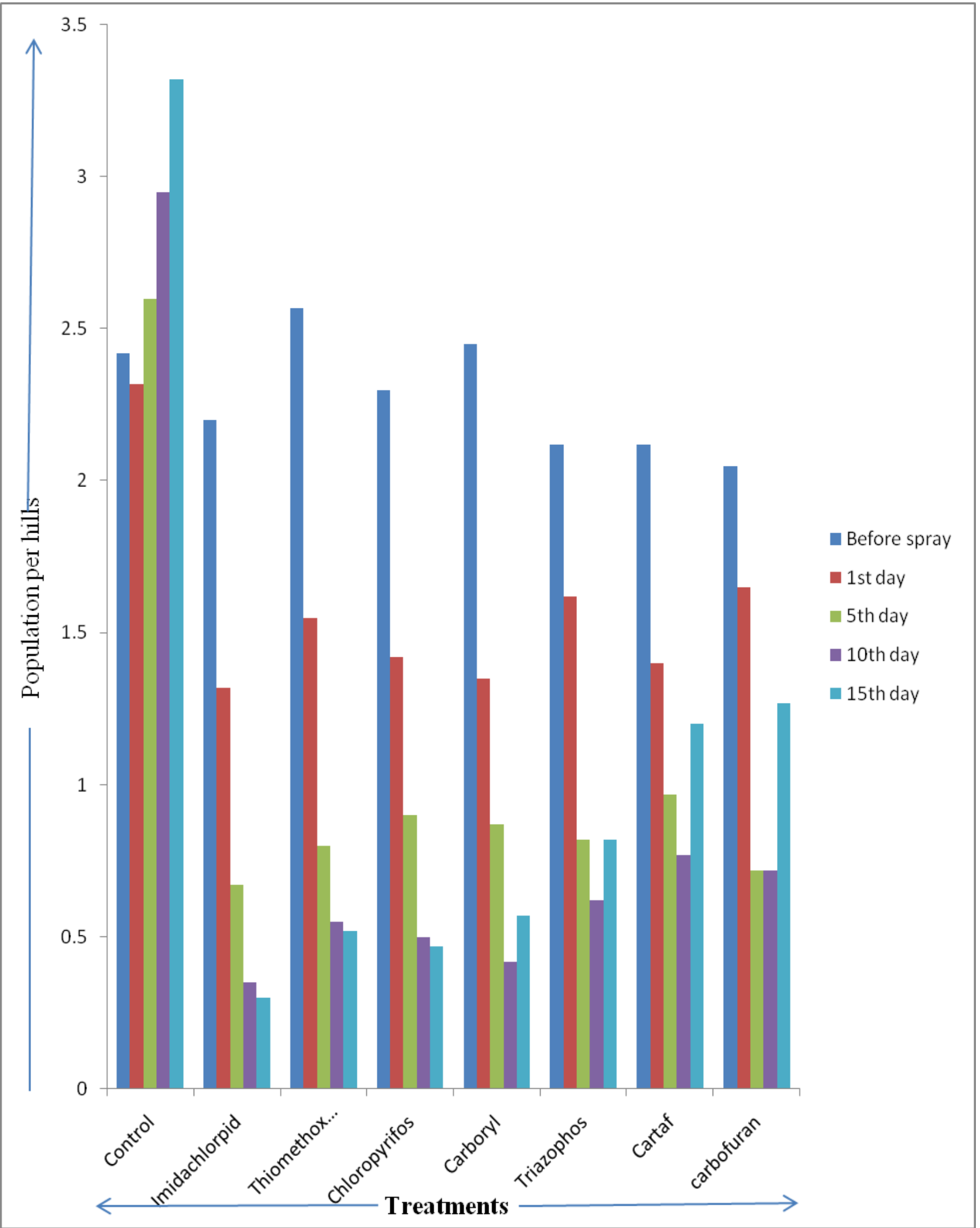


The probable reason for such findings may be that the insecticides after penetrating inside the body of insect may have reached the synoptic sites and may have mimicked the acetyl choline and reacted with enzyme acetyl choline esterase and inhibited it by blocking its active sites which are responsible for hydrolysis of natural substrate acetyl choline.

This enzyme inhibition may have lead to the accumulation of acetyl choline at the nerve endings which may have ultimately resulted in restlessness, tremors, paralysis and death of the target insect.

\section{References}

Choudhary, 2014. Incidences of gundhi bug and steps for control. Protocol Rice Research Works Management. CRRI, Cuttack. pp. 297-299.

Dey, Utpal, Sarkar, B.B., Dhutraj, D.N. and Badgujar, S.L. 2013. Deterioration of rice grain quality due to rice earhead bug, (Leptocorisa acuta) Thunb.in Tripura. International Journal of Plant Protection. 6 (1): 35-37.

Prasad, R., and Prasad, D. 2006. Account of insect problem in rice ecosystem in
Ranchi. Indian Journal of Entomology. 68 (3): 240-246

Rath, P.C., 2012. Field evaluation of newer insecticides against insect pest of rice. Indian journal of plant protection, 40 (2):148-149

Rath, P.C., Chakraborty, K., Nandi, P. and Moitra, M. N. 2015. Field efficacy of some new insecticides against rice stem borer and gundhi bug in irrigated rice ecology. International Journal of Plant, Animal and Environmental Sciences. 5 (2): 94-96

Tiwari, Amit, 2014. Effectiveness of insecticide and biopesticide against gundhi bug of rice crop in district Rewa (M.P.), India. Indian Journal of Plant Science 5 (2): 124-126

Visalakshmi, V., Satyanarayana, H., Kumar, N. M. and Rao, U. A. 2016. Efficacy of new insecticide molecules against major pests of rice. International Journal of Farm Sciences 6 (2): 169-175.

Yaduman, R., Lal, A. A., Singh, A., Singh, S. and Simon S. 2015. Efficacy of insecticides and botanicals against rice gundhi bug (Leptocorisa acuta). The Allahabad Farmer Journal, 1(1):167168.

\section{How to cite this article:}

Brajesh Bais, Ashwani Kumar, Hadi Husain Khan, Ramkinkar Sahu and Pramod Kumar Kaiwart. 2017. Efficacy of Certain Chemical Insecticides against Rice Gundhi Bug (Leptocorisa acuta Thunberg) Under Field Condition. Int.J.Curr.Microbiol.App.Sci. 6(9): 1697-1701. doi: https://doi.org/10.20546/ijcmas.2017.609.209 